\begin{tabular}{|c|c|c|}
\hline & Int.J.Curr.Microbiol.App.Sci (2021) 10(10): 267-276 & \\
\hline FXCIIFNT & $\begin{array}{l}\text { International Journal of Current Microbiology and Applied Sciences } \\
\text { ISSN: 2319-7706 Volume } 10 \text { Number } \mathbf{1 0}(\mathbf{2 0 2 1 )} \\
\text { Journal homepage: } \underline{\mathrm{http}: / / \text { www.ijcmas.com }}\end{array}$ & $\$$ \\
\hline $\begin{array}{l}\text { EXCELLENT } \\
\text { PUBLISHERS }\end{array}$ & & \\
\hline
\end{tabular}

Original Research Article

https://doi.org/10.20546/ijcmas.2021.1010.032

\title{
Development and Sensory Evaluation of Quinoa Based Sweet and Salt cookies
}

\author{
Kale Bala Nirmala* and Mukul Sinha \\ Department of Food and Nutrition, College Of Community Science, Dr. Rajedra Prasad \\ Central Agricultural University, Pusa, Bihar, India \\ *Corresponding author
}

\begin{tabular}{|l|}
\hline Key w o r d s \\
$\begin{array}{l}\text { Wheat, barley, } \\
\text { lipids, calcium, } \\
\text { iron, folate }\end{array}$ \\
\hline Article Info \\
\hline $\begin{array}{l}\text { Accepted: } \\
\text { 10 September } 2021 \\
\text { Available Online: } \\
10 \text { October } 2021\end{array}$ \\
\hline
\end{tabular}

A B S T R A C T

Gluten, a visco elastic protein present in the wheat causes damage to the small intestine and as a result the microvilli of the small intestine gets atrophed. This situation leads to abdominal discomfort and malaborption of many vital vitamins. This condition is called as Gluten Sensitivity or Celiac Disease, following a gluten free diet is most suitable treatment. Gluten free cereals can be used in diet, but they can't replace wheat in bakery products. The present study was conducted to develop gluten free cookies with quinoa, a nutrient dense pseudocereal. Three different types of cookies using two different types of quinoa flour were prepared. Sensory evaluation and nutritive value of the cookies revealed that Quinoa cookies have excellent sensory attributes and also they are high in nutritive value. Among all cookies made corn flake cookies (C1) cookies are much more appreciated than cinnamon cookies (C2) and salt cookies (C3).

\section{Introduction}

Celiac disease is a chronic gastrointestinal disease which affects genetically predisposed persons and causes damage to the lining of the small intestine as a result of a protein called "gluten" found in grains such as wheat, barley, and rye. The gut is damaged, making it difficult for the body to absorb nutrients such as lipids, calcium, iron, and folate (Porcel et al., 2017). However, for those who suffer from this condition, a gluten-free diet is the only standard therapy (Eunice et al., 2020). But following gluten free diet is not easy as it sounds because most of daily consumed biscuits, cookies, bread and wheat based products depends on viscoelastic nature of the gluten, which is a structure-forming protein present in various grains that influences the elastic qualities of dough and adds to the overall aesthetic and crumb structure of many baked goods. Cereal-based cookies, crackers, and breakfast cereals and cereal products are foods that provide a significant amount of 
energy to individuals. Cookies are widely accepted and consumed in many countries because they offer a diverse variety of snack options with a long shelf life and low cost. Texture, flavour, and appearance are the three primary factors that influence cookie quality. Another essential component of developing cookies with enhanced nutritional status is maintaining the product's sensory qualities, because customer acceptance is still the most significant factor in determining whether or not a newly produced product will be successful. The undissolved sugar gradually dissolves while baking, contributing to cookie spread. Cookie hardness, crispness, colour, and volume are all impacted by the sugar content of the recipe.

Following gluten free diet can cause micronutrient deficiency due to deficiency of nutrients in traditionally consumed gluten free cereals such as Rice, Ragi, Sorghum, jowar. The other problems include lack of dietary fibre and excess of transfat making the gluten free cereals unfit for nutritious and tasty cookies for gluten free population.

To overcome these problems, people now a days are giving lot of priority to food grains with nutrient dense and Quinoa turned out to be excellent substitute for gluten free cereals.

Quinoa is usually referred to as a pseudocereal since it is not a member of the Graminae family but it produces seeds that can be milled in to flour and used as a cereal crop. It is highly resistant to weather, climate, and soil conditions (Valencia, 2011). It is called as 'golden grain' because of its ability where it can grow in adverse conditions like cold, drought and salt and can adopt to high temperature (Hinojosa, 2018). It can grow in a place with annual rainfall within a range of 200-400 nm and even at high precipitated countries like Chile with $3000 \mathrm{~mm}$ precipitation factor (Angeli, 2020).
With its ability to withstand to weather and soil conditions, Quinoa can provide food security where malnutrition is prevalent making it one of the most demandable pseudo cereal. Quinoa has not only excellent nutrients but also adding taste and variety to the meal.

The present study was planned with the aim of development and sensory evaluation of value added gluten free cookies which can be welcomed by general population where they can enjoy cookies along with a cup of tea over breakfast.

\section{Materials and Methods}

\section{Procurement of raw materials and processing of flour}

The Quinoa seeds were purchased from a authorized dealer, the other ingredients such as oasts, cornflour, sugar, buttter etc were purchased from local markets. Two types of flours i'e: RQS flour (dry roasting for 5-6 minutes) Quinoa seeds flour as well as URQS flour (Soaking in water for 4-5 hrs).

\section{Method of preparation}

\section{Corn Flake Cookes / Cinnamon Cookies (C2)}

Fat and sugar was creamed together till lightly and puffy.

Vanilla essence was added and mixed thoroughly.

The flour was added to cream and mixed into smooth dough using milk.

Cornflakes/Cinnamon Powder was added to the dough and mixed once again.

The dough was divided into round balls using wet hands. 
The round balls were placed on greased and dusted baking trays and crushed cornflakes* were sprinkled on the top of surface and baked at $200^{\circ} \mathrm{C}$ for 20 minutes.

\section{Salt Cookies (C3)}

Butter was creamed light and puffy.

Quinoa flour, oats flour and corn flours were taken in a bowl.

Salt and butter were added to the flours and mixed thoroughly and made into a smooth dough using water.

The dough was divided into round balls using wet hands.

The round balls were placed on greased and dusted baking trays and pressed slightly and baked at $200^{\circ} \mathrm{C}$ for 20 minutes.

\section{Sensory Analysis}

After preparation of cookies, Sensory evaluation was conducted using 9-point Hedonic Rating Scale, judges were asked to rate the samples on appearance, colour, texture, flavour, taste, and overall acceptability.

The expression "liked very much" was given at 9 score, "neither like nor dislike" was given 5 score, and "disliked extremely" was given 1 score (Schumacher et al., 2010).

\section{Statistical Analysis}

Mean and standard deviation for twenty parallel observations was calculated. Paired $t$ test was used to test the difference between samples prepared with RQS flour and URQS flour. Paired t test was applied between RQS flour and URQS flour based products.

\section{Results and Discussion}

\section{Organoleptic scores of Quinoa Cookies}

The organoleptic scores of the Quinoa cookies were analyzed and presented in the tables(1).

\section{Appearance}

The foremost important attribute which appeases the acceptance of food was its appearance. Appearance of $\mathrm{C} 1$ cookies made with both RQS flour and URQS flour was much delighted with a similar score of $8.3 \pm$ 0.80 and $8.3 \pm 0.86$ followed by $\mathrm{C} 2$ cookies with $7.65 \pm 0.81$ and $7.55 \pm 0.88$ and $\mathrm{C} 3$ cookies with similar score of $7.5 \pm 0.67$ and $7.65 \pm 0.74$.

\section{Colour}

The brownish cinnamon cookies (C2) was less appreciated with RQS flour based cookies scoring $7.6 \pm 0.75$ and URQS flour based cookies comparatively scoring $7.5 \pm 0.76$ than much lighter salt cookies (C3) with $7.6 \pm 0$. $59,7.7 \pm 0.80$ and where as golden coloured corn flake cookies $(\mathrm{C} 1)$ with $8.55 \pm 0.82,8.25$ \pm 0.85 tops in the colour. Except in salt cookies, RQS based cookies scored better than URQS based products.

\section{Taste}

The salt cookies (C3) made with RQ flour was least scored with $7.3 \pm 0.65$ in taste because of its slight bitter taste. The cinnamon cookies (C2) and salt cookies (C3) made with URQS flour was similar in scores with $7.7 \pm 0.97,7.8$ \pm 0.95 and $7.8 \pm 0.69$. The taste of corn flake cookies (C1) was given similar high scores of $8.35 \pm 0.87$ in both RQS and URQS flour based products. Except corn flakes cookies, the taste of URQS based cookies is much liked than RQS based cookies. 


\section{Texture}

The combination of Texture and flavour forms the sensory image and consider crucial in sensory characteristics of cookies. Score of RQS cinnamon cookies (C2) texture was slightly lesser URQS cinnamon cookies (C2) with $7.4 \pm 1.14,7.6 \pm 0.88$, the similar pattern was observed in salt cookies (C3) with $7.65 \pm 0.58,7.75 \pm 0.71$. The texture of corn flake cookies (C1) varies between RQ $(8.05 \pm 0.94)$ and URQ (8.3 \pm 0.80$)$. URQS based products has better texture than RQS based cookies.

\section{Flavour}

The flavour of salt cookies (C3) were lower than other cookies but both RQ and URQ has similar scores with $7.55 \pm 0.51$ and $7.45 \pm 0.60$. flavour of URQ Cinnamon cookies (C2) was better scored than RQ Cinnamon cookies (C2) $(7.8 \pm 0.69>7.4 \pm 0.75)$. the scores revealed that corn flake cookies (C1) flavour higher than both cinnamon and salt cookies with URQS cookies flavour $(8.25 \pm 0.85)$ is more acceptable than RQS cookies $(8.1 \pm 1.02)$. Flavour of RQS based corn flake and cinnamon cookies were much liked than URQS based cookies.

\section{Overall Acceptability}

The overall acceptability of cookies didn't varied between RQ and URQ rather the difference more evident in cookies with corn flake cookies (C1) scoring high overall acceptability score of $8.35 \pm 0.87,8.3 \pm 0.80$ followed by cinnamon cookies (C2) $(7.75 \pm$ 0.71 and $7.5 \pm 0.76$ ) and Salt cookies (C3) $(7.65 \pm 0.67$ and $7.55 \pm 0.68)$. The quinoa cookies were highly accepted with overall acceptability score ranges from $7.55 \pm 0.68$ to $8.35 \pm 0.87$ on 9 point hedonic scale means they were liked moderately to liked very much. $\mathrm{C} 1$ Cookies were very much liked in all aspects of sensory evaluation with all scores more than 8 which interprates that they were liked very much to liked extremely on the hedonic scale.

Table.1 Raw materials

\begin{tabular}{|c|c|c|c|}
\hline Name of ingredients & $\begin{array}{c}\text { Corn flake Cookies } \\
\text { ( C1) }\end{array}$ & $\begin{array}{c}\text { Cinnamon cookies } \\
\text { (C2) }\end{array}$ & Salt cookies (C3) \\
\hline 1. Quinoa flour & $22 \mathrm{~g}$ & $22 \mathrm{~g}$ & $35 \mathrm{~g}$ \\
\hline 2. Oats flour & $13 \mathrm{~g}$ & $13 \mathrm{~g}$ & $13 \mathrm{~g}$ \\
\hline 3. Corn flour & $8.5 \mathrm{~g}$ & $8.5 \mathrm{~g}$ & $20 \mathrm{~g}$ \\
\hline 4.Sugar & $25 \mathrm{~g}$ & $25 \mathrm{~g}$ & - \\
\hline 5.Butter & $17 \mathrm{~g}$ & $17 \mathrm{~g}$ & $19 \mathrm{~g}$ \\
\hline $\begin{array}{c}\text { 6.cornflakes/cinnamon } \\
\text { powder/salt }\end{array}$ & $\begin{array}{c}5 \mathrm{~g} \\
\text { (Cornflakes) }\end{array}$ & $\begin{array}{c}5 \mathrm{~g} \\
\text { (cinnamon powder) }\end{array}$ & $\begin{array}{c}\mathrm{g} \\
\text { (salt) }\end{array}$ \\
\hline 7.Milk/Water & $10 \mathrm{ml}$ & $10 \mathrm{ml}$ & $10 \mathrm{ml}$ \\
\hline
\end{tabular}


Table.2 Scores based on Sensory Evaluation of Quinoa Cookies (Plain cookies, Cinnamon cookies (C2) and Salt cookies (C3))

\begin{tabular}{|c|c|c|c|c|c|c|c|c|c|c|}
\hline S. No. & Parameters & RQC2 & URQC2 & Tvalue & RQCC2 & URQCC 2 & t-value & RQSC & URQSC & t-value \\
\hline 1 & Appearance & $8.3 \pm 0.80$ & $8.3 \pm 0.86$ & ${ }_{0} \mathrm{NS}$ & $7.65 \pm 0.81$ & $7.55 \pm 0.88$ & $\begin{array}{c}0.48 \\
\mathrm{NS}\end{array}$ & $7.5 \pm 0.67$ & $7.65 \pm 0.74$ & $0.71^{\mathrm{NS}}$ \\
\hline 2 & Colour & $8.55 \pm 0.82$ & $8.25 \pm 0.85$ & $\begin{array}{l}1.55 \\
\text { NS }\end{array}$ & $7.6 \pm 0.75$ & $7.5 \pm 0.76$ & $\begin{array}{c}0.56 \\
\text { NS }\end{array}$ & $7.6 \pm 0.59$ & $7.7 \pm 0.80$ & $\begin{array}{l}\text { 0.46 } \\
\text { NS }\end{array}$ \\
\hline 3 & Taste & $8.35 \pm 0.87$ & $8.35 \pm 0.87$ & ${ }_{0} \mathrm{NS}$ & $7.7 \pm 0.97$ & $7.8 \pm 0.95$ & ${ }_{0} \mathrm{NS}$ & $7.3 \pm 0.65$ & $7.8 \pm 0.69$ & $2.36 *$ \\
\hline 4 & Texture & $8.05 \pm 0.94$ & $8.3 \pm 0.80$ & $\begin{array}{l}1.09 \\
\mathrm{NS}\end{array}$ & $7.4 \pm 1.14$ & $7.6 \pm 0.88$ & $\begin{array}{c}0.67 \\
\text { NS }\end{array}$ & $7.65 \pm 0.58$ & $7.75 \pm 0.71$ & $\begin{array}{c}\text { 0.39 } \\
\text { NS }\end{array}$ \\
\hline 5 & Flavour & $8.1 \pm 1.02$ & $8.25 \pm 0.85$ & $\begin{array}{c}0.61 \\
\text { NS }\end{array}$ & $7.4 \pm 0.75$ & $7.8 \pm 0.69$ & $\begin{array}{l}1.70 \\
\text { NS }\end{array}$ & $7.55 \pm 0.51$ & $7.45 \pm 0.60$ & $\begin{array}{l}0.62 \\
\text { NS }\end{array}$ \\
\hline 6 & Overall Acceptability & $8.35 \pm 0.87$ & $8.3 \pm 0.80$ & $\begin{array}{c}0.25 \\
\text { NS }\end{array}$ & $7.5 \pm 0.76$ & $7.75 \pm 0.71$ & $\begin{array}{c}1.31 \\
\text { NS }\end{array}$ & $7.65 \pm 0.67$ & $7.55 \pm 0.68$ & $\begin{array}{c}0.49 \\
\text { NS }\end{array}$ \\
\hline
\end{tabular}


Table.3 Nutritive value of Quinoa Cookies

\begin{tabular}{|c|c|c|c|}
\hline & Plain Cookies & Cinnamon cookies (C2) & Salt cookies (C3) \\
\hline Energy & $\mathbf{3 3 7 . 9 5}$ & 318.95 & 303.07 \\
\hline Fat & 8.93 & 8.88 & $\mathbf{9 . 8 9}$ \\
\hline Protein & 4.56 & 4.23 & $\mathbf{6 . 2}$ \\
\hline Carbohydrates & $\mathbf{5 8 . 9 6}$ & 54.61 & 46.91 \\
\hline Fibre & 4.15 & 4.02 & $\mathbf{6 . 4 3}$ \\
\hline Vitamin A & $\mathbf{1 2 . 9 7}$ & 7.97 & 7.04 \\
\hline Vitamin E & 0.46 & 0.46 & $\mathbf{0 . 7 1}$ \\
\hline Vitamin K & $\mathbf{0 . 4 4}$ & 0.44 & 0.7 \\
\hline Thiamine & $\mathbf{4 . 7 3}$ & 4.68 & 0.29 \\
\hline Riboflavin & $\mathbf{1 2 . 8}$ & 12.74 & 0.07 \\
\hline Niacin & $\mathbf{1 1 . 6 3}$ & 10.97 & 0.59 \\
\hline Pyridoxine & $\mathbf{0 . 1 2}$ & 0.04 & 0.07 \\
\hline Calcium & 58.14 & 58.14 & $\mathbf{6 7 . 2}$ \\
\hline Zinc & 0.72 & 0.72 & $\mathbf{1 . 1 5}$ \\
\hline Iron & $\mathbf{2 . 6 9}$ & 1.81 & 0.88 \\
\hline
\end{tabular}


Fig.1 RQS Corn flake cookies (C1)

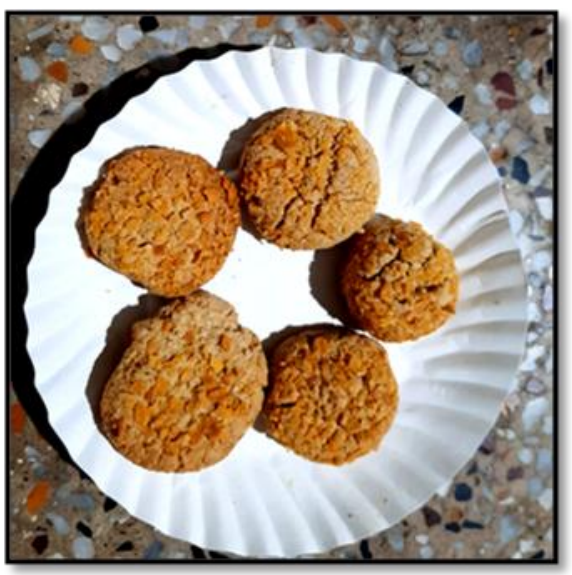

Fig.3 RQS Cinnamon cookies (C2)

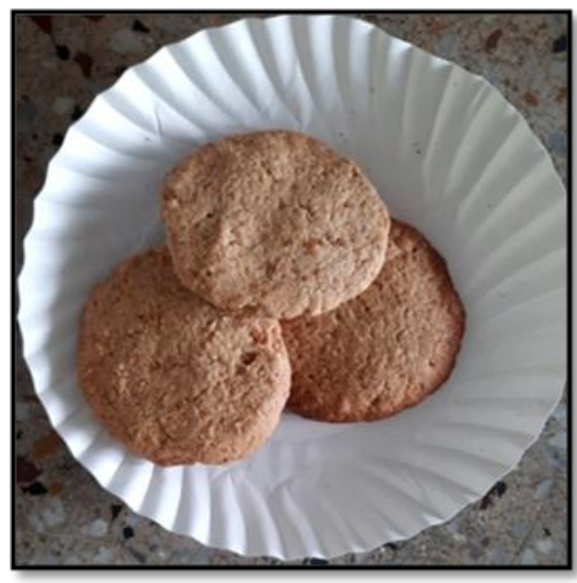

Fig.5 RQS Salt Cookies (C3)

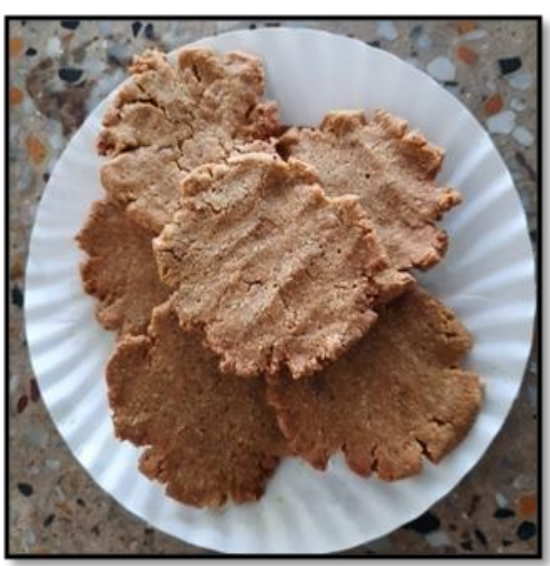

Fig.2 URQS Corn flake Cookies (C1)

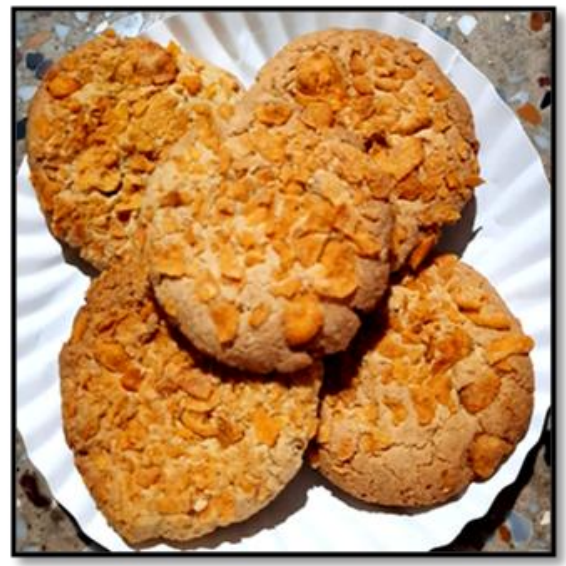

Fig.4 URQS Cinnamon Cookies (C2)

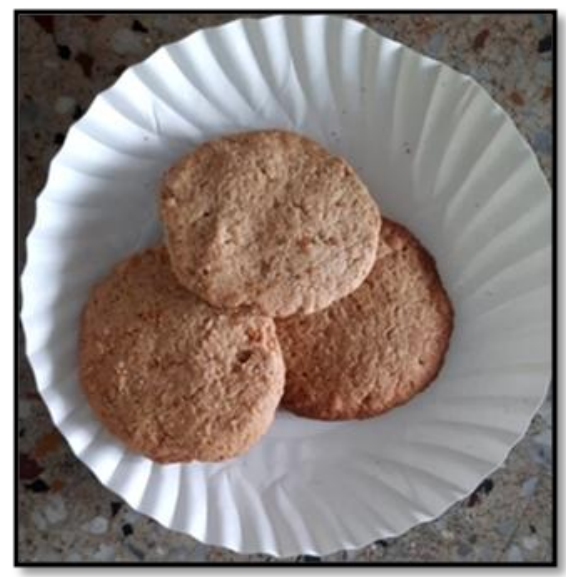

Fig.6 URQS Salt Cookies (C3)

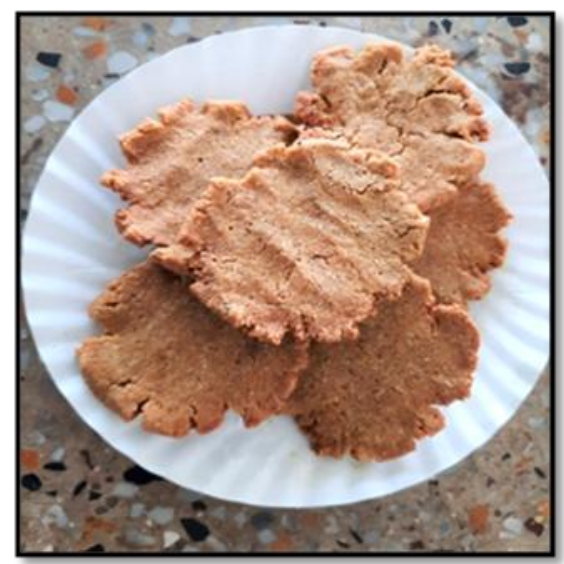


Int.J.Curr.Microbiol.App.Sci (2021) 10(10): 267-276

Fig.7

figure 9. Representation of Sensory scores of quinoa cookies

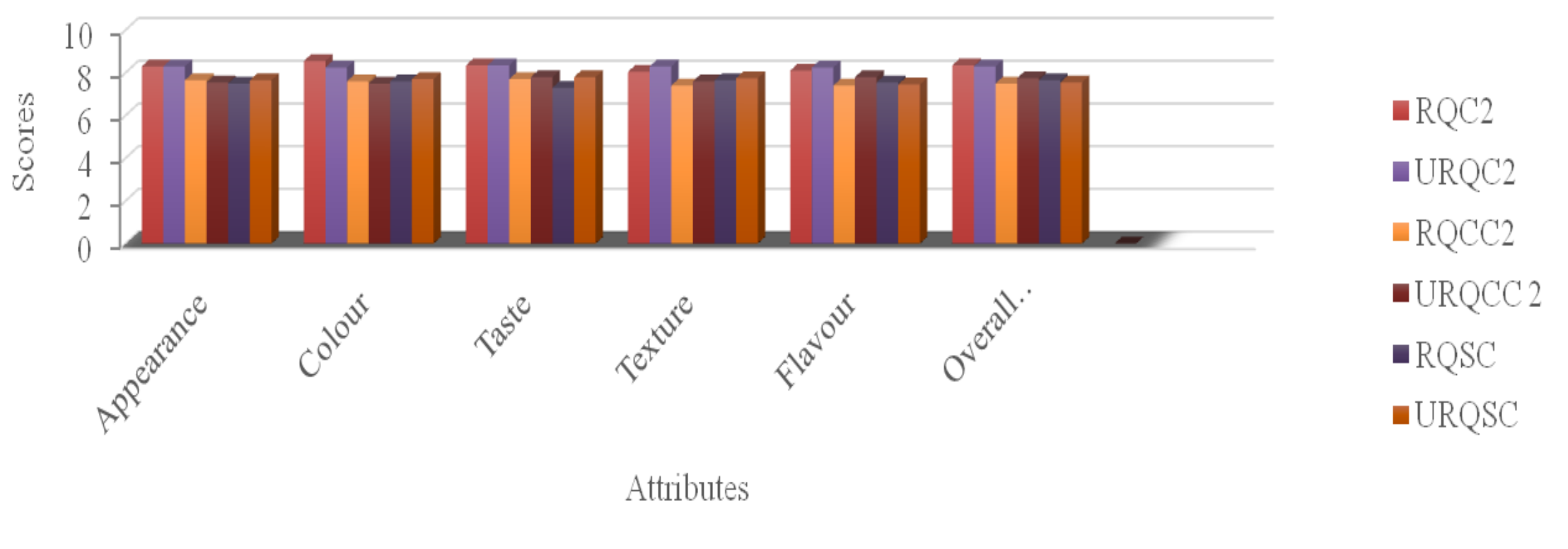


The Significant difference at 5\% level of significance was found only in taste $(\mathrm{t}$ - value: 2.36) attribute of salt cookies (C3). The results were higher when compared to Sukmandeep (2016) where cookies made with quinoa, oats and rice flour in the proportion of 10:45:45 ratio which got overall acceptability score of $7.46 \pm$ 0.45. Bhatkal (2016) prepared gluten free products with $100 \%$ quinoa flour and organoleptic scores were like 8.10, 8.0, 7.70, $8.00,7.90$ and overall acceptability score of 7.94 which was more than the cookies in the control i.e., 7.28.

Mayra (2018) prepared gluten free cookies using Rice flour(RF), Corn flour (CF) and Quinoa flour (QF) in three different formulations, Formulation 1, 2 and 3 consists of $\mathrm{RF}, \mathrm{CF}$ and $\mathrm{QF}$ in the proportion of 60:30:10 and 70:10:20 and 60:10:30 and concluded that Formulation 3 was not accepted due to its poor organoleptic scores.

Brito et al., (2015) Gluten-free quinoa cookies with $30 \%$ quinoa flour, $25 \%$ quinoa chips and $45 \%$ corn starch. In comparison to the control batch, these cookies were high in essential amino acids, linolenic acid, minerals, and dietary fibre and The overall acceptability of the optimised quinoa-based cookie received an average score of 6.8, which corresponds to "liked." Pagamunici et al., (2014) produced gluten-free cookies using rice and quinoa flour in proportions of 15,26 , and $36 \%$ quinoa flour.

According to 80 non-trained customer panelists, the formulation of 36.0 percent quinoa flour had as well as outstanding sensory characteristics. The cookies were highly received since the acceptance percentage was greater than $70 \%$.

\section{Nutritive Value of Quinoa Cookies}

Table(2) represents the calculated nutritive value of quinoa cookies based on the weight of raw ingredients mentioned in Indian Food Composition Table (2017). From the table, it is evident that quinoa cookies are not only tasty but also nutritious.

Salt cookies (C3) provide less carbohydrates(46.91g) and energy(303. 07 k.cal), high fibre (6.43g) than sweet cookies i.e., Corn flake cookies $(\mathrm{C} 1)$ and Cinnamon cookies (C2) (C3) (54.61g and 58.96 g, 318.95 k.cal and 337.95 K.Cal, $4.02 \mathrm{~g}$ and $4.15 \mathrm{~g}$ ) per $100 \mathrm{~g}$ of quinoa cookies which can be helpful in weight reduction. Even though the nutrient content differs from salt cookies (C3) but it's nutritive value is cannot be ignored. Using FAO/WHO recommendation(2003) of fibre intake ( 25 to $30 \mathrm{~g}$ of fibre per day) for adults to help avoid diet-related chronic illnesses, four quinoa cookies (as cooked) would provide approximately $25 \%$ of the minimum daily required fibre intake.

Protein $(4.23 \mathrm{~g}, 4.56 \mathrm{~g}$ and $6.2 \mathrm{~g})$ and fat $(8.83 \mathrm{~g}$, $8.88 \mathrm{~g}$ and $9.89 \mathrm{~g}$ ) are present in moderant quantities which makes quinoa as excellent substitute for wheat in bakery products. Quinoa is one of very few grains that consists of all essential amino acids and considering the amount of protein even without egg explains the importance of quinoa. The fat is present in quinoa is majorly made up of polyunsaturated fatty acids, monounsaturated fatty acids and less transfat. $100 \mathrm{~g}$ quinoa cookies(Corn flake Cookies) can provide 4.73 $\mathrm{mg}, 12.8 \mathrm{mg}$ and $11.63 \mathrm{mg}$ of Thiamine, Riboflavin and Niacin which are important vitamins in energy and protein metabolism. The calculated values were higher than recommended RDA of these nutrients for reference man and woman (RDA, 2020) which implies the health benefits of quinoa cookies. The other important minerals that is present in cookies are calcium $(58.14,58.14$ and 64.4), Zinc $(0.72,1.15)$ and Iron (0.88, 1.18 and 2.69) These minerals have critical roles in maintaining health, cell growth and 
proliferation, metabolism, development, and immune function.

The results of sensory evaluation and calculated nutritive value of quinoa cookies proved that Quinoa cookies presents both health benefits and taste. These results indicate that quinoa (processed into flour) might be used as a gluten-free bakery ingredient in combination with maize flour and oat flour, especially in cookies for the gluten sensitive people who suffers from lack of nutrients.

\section{References}

Angeli, V., Miguel Silva, P., Crispim Massuela, D., Waleed Khan, M., Hamar, A., Khajehei, F., and Piatti, C. (2020). Quinoa (Chenopodium quinoa Willd.): An overview of the potentials of the "golden grain" and socioeconomic and environmental aspects of its cultivation and marketization. Foods. 9: 216.

Bhathal, S. K., Kaur, N., and Gill, J. (2017). Effect of processing on the nutritional composition of quinoa (Chenopodium quinoa Willd). Agricultural Research Journal: 54: 90-93.

Brito, I. L., de Souza, E. L., Felex, S. S. S., Madruga, M. S., Yamashita, F., and Magnani, M. (2015). Nutritional and sensory characteristics of gluten-free quinoa (Chenopodium quinoa Willd)based cookies development using an experimental mixture design. Journal of food science and technology. 52:
5866-5873.

Eunice, A. T., Phebean, I. O., Samuel, O., Edith, E. N., and Dorcas, A. O. (2020). Production of gluten-free cookies from blends of malted sorghum (S. bicolor) and tiger nut (Cyperus esculentus) flour. American Journal of Food Science and Technology, 8(3), 106111.

Kaur, S., Kaur, N., and Grover, K. (2018). Development and Nutritional Evaluation of Gluten Free Bakery Products Using Pseudocereal quinoa (Chenopodium quinoa). International Journal of Pure and Applied Biosciences. 6: 810-820.

Mayra, A. G. V., Josefa, P., Dunellys, R., \& J P, E. P. (2018). Development of Cookies and Muffins based on Rice, Quinoa and Corn Flours. Advance Journal of Food Science and Technology, 16(S), 226-228.

Pagamunici, L. M., Gohara, A. K., Souza, A. H., Bittencourt, P. R., Torquato, A. S., Batiston, W. P., and Matsushita, M. (2014). Using chemometric techniques to characterize gluten- free cookies containing the whole flour of a new quinoa cultivar. Journal of the Brazilian Chemical Society. 25: 219 228.

Ostermann-Porcel, M. V., Quiroga-Panelo, N., Rinaldoni, A. N., \& Campderrós, M. E. (2017). Incorporation of okara into gluten-free cookies with high quality and nutritional value. Journal of Food Quality, 2017.

\section{How to cite this article:}

Kale Bala Nirmala and Mukul Sinha. 2021. Development and Sensory Evaluation of Quinoa Based Sweet and Salt cookies. Int.J.Curr.Microbiol.App.Sci. 10(10): 267-276. doi: https://doi.org/10.20546/ijcmas.2021.1010.032 